\title{
Prevalensi anomali jumlah gigi ditinjau dari radiografi panoramik di RSGM UNHAS Makassar
}

\author{
Barunawaty Yunus ${ }^{\text {* }}$, Kahfi Iczanul Iman²
}

\begin{abstract}
Objectives: Abnormalities in the number of teeth is a change of dental structure that arises from abnormalities during tooth formation, can be due to congenital or growth. For anomalies, the number of teeth consists of anadontia and supernumerary teeth. This research is aimed to obtain a general picture of the prevalence of abnormalities in the number of teeth in terms of panoramic radiographs at RSGM UNHAS.
\end{abstract}

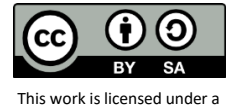

Material and Methods: This type of research is observational descriptive and the design of this study is cross sectional study. The research subjects were all panoramic radiographic photo data in the Teaching and Mouth Hospital of Hasanuddin University in the last 1 year. Data is processed in tables and diagrams.

Results: The results showed that the majority of anadontia prevalence by sex occurred in women, as a breakdown of hypodontia with a presentation of $68.04 \%$, oligodontia with a presentation of $26.93 \%$ and anadontia with a presentation of $5.21 \%$. The prevalence of anadontia based on the majority age group occurs in the adult age group, as a breakdown of hypodontia with a presentation of $77.73 \%$, oligodontia with a presentation of $21.40 \%$, and anadontia with a presentation of $0.87 \%$. The prevalence of anadontia by month occurred at most in August 2018 with 70 people, while the lowest number was in July 2018 with 1 person. The prevalence of supernumerary teeth based on the majority sex occurs in male patients with a total of 4 people, as detailed mesiodens with $25 \%$ presentation, laterodens with $75 \%$ presentation, and no distomolar.

Conclusion: The prevalence of anomaly deficiency in the number of teeth by sex is most experienced by women, the prevalence of supernumerary teeth is more experienced by men. When viewed from the age group, abnormalities in the number of teeth are most experienced by the adult age group and supernumerary teeth are most experienced by the adolescent age group.
${ }^{1}$ Departemen Radiologi Kedokteran Gigi, Fakultas Kedokteran Gigi, Universitas Hasanuddin, Makassar Indonesia, 90245

${ }^{2}$ Program Studi Pendidikan Dokter Gigi, Fakultas Kedokteran Gigi, Universitas Hasanuddin, Makassar, Indonesia, 90245

*Correspondence to:

Barunawaty Yunus

■barunawaty@yahoo.com

Received on: October 2019 Revised on: January 2020 Accepted on: March 2020

Keywords: Radiography, panoramic radiography, anadontia, supernumerary teeth

Cite this article: Yunus B, Iman KI. Prevalensi anomali jumlah gigi ditinjau dari radiografi panoramik di RSGM UNHAS Makassar. Jurnal Radiologi Dentomaksilofasial Indonesia 2020;4(1)17-22. https://doi.org/10.32793/jrdi.v4i1.475

\section{PENDAHULUAN}

Anomali gigi adalah perubahan dari struktur dental yang muncul dari anomali saat pembentukan gigi, bisa karena bawaan ataupun pertumbuhan. Anomali gigi bisa terjadi karena beberapa faktor termasuk lingkungan dan pengaruh genetik. Anomali pertumbuhan adalah kejadian yang sering terjadi saat proses pertumbuhan gigi. Anomali gig meliputi jumlah, morfologi, ukuran dan perubahan saat erupsi. Anomali tersebut bisa menyebabkan komplikasi pada perawatan dental, seperti perawatan saluran akar dan pencabutan gigi, dan bisa menyebabkan maloklusi. ${ }^{1}$

Banyak hipotesis yang berbeda telah dikemukakan tentang etiologi anomali jumlah gigi, sehingga saat ini tidak ada yang dapat dikatakan dengan pasti sebagai etiologi, tetapi sifat herediter mempunyai peranan dengan melihat ras dan tendensi keluarga. Faktor lingkungan dapat menyebabkan pecahnya benih gigi ketika bayi masih dalam kandungan, misalnya radiasi atau penyinaran, trauma, infeksi gangguan nutrisi dan hormonal. $^{2}$

Perkembangan gigi-geligi melalui proses kompleks yang disebut juga odontogenesis, dalam mekanisme pembentukan gigi terbagi dalam tahap morfologi dan tahap fisiologis. Jika pada prosesnya tidak berjalan dengan baik maka dapat menyebabkan abnormalitas pertumbuhan pada gigi baik itu kelebihan gigi atau kekurangan gigi (supernumerary teeth atau anadontia). Kemungkinan anadontia sering ditemukan pada gigi yang berkembang terakhir dari setiap kelas morfologi gigi, yakni insisivus lateral, premolar dua, dan molar tiga. $3,4,5$

Bentuk gigi desidui sudah mulai berkembang pada usia 4 bulan dalam kandungan. Pertumbuhan dan perkembangan gigi melalui beberapa tahap, yaitu tahap inisiasi, proliferasi, histodiferensiasi, morfodiferensiasi, aposisi, kalsifikasi dan erupsi. Pada masing-masing tahap dapat terjadi anomali 
yang menyebabkan anomali dalam jumlah gigi, ukuran gigi, bentuk gigi, struktur gigi, warna gigi dan gangguan erupsi gigi. Jumlah gigi manusia yang normal adalah 20 gigi sulung dan 32 gigi tetap, tetapi dapat dijumpai jumlah yang lebih atau kurang dari jumlah tersebut. Anomali jumlah gigi adalah dijumpainya gigi yang berlebih karena benih berlebih atau penyebab lain dan kekurangan jumlah gigi disebabkan karena benih gigi yang tidak ada atau kurang. ${ }^{2}$

Anadontia dapat mengenai satu atau beberapa gigi, bahkan dapat mengenai seluruh gigi dan dapat terjadi pada gigi sulung maupun gigi tetap. Anadontia terbagi lagi menjadi tiga bagian, yaitu hipodonsia, oligodonsia, dan anodonsia. Hipodonsia adalah tidak terdapatnya satu atau beberapa gigi, oligodonsia adalah tidak adanya sejumlah gigi, biasanya lebih dari enam gigi dan umumnya dihubungkan dengan sindroma spesifik dan atau anomali abnormal yang berat, sedangkan anodonsia merupakan bentuk ekstrim dari oligodonsia yang menunjukkan tidak adanya seluruh gigi. ${ }^{6}$

Berbagai konsep tentang etiologi anodonsia telah banyak diajukan pada beberapa literatur. Berbagai teori tentang gigi anodonsia menjelaskan bahwa etiologinya adalah multifaktorial yang berhubungan dengan regulasi genetik dan faktor lingkungan. Hal ini diikuti oleh teori yang mengelilingi anodonsia dan sebuah diskusi yang lebih detail mengenai faktor spesifik, baik itu genetik maupun lingkungan, yang berhubungan langsung pada kondisi ini. ${ }^{6}$

Penelitian lainnya melaporkan bahwa jenis kelamin juga turut mempengaruhi prevalensi bawaan dari anadontia. Beberapa penelitian telah melaporkan prevalensi gigi yang mengalami anadontia secara signifikan lebih tinggi pada wanita, sementara penelitian ini serta beberapa orang lain tidak menemukan seperti perbedaan yang signifikan antara prevalensi anadontia terhadap laki -laki dan perempuan. Hasil Penelitian menyatakan rasio laki-laki dan perempuan 1:1.37 dan 1:1.4. ${ }^{7}$

Hiperdonsia atau supernumerary teeth didefinisikan sebagai berlebihnya jumlah gigi pada individu tertentu, yaitu melebihi jumlah gigi normal dari 20 gigi sulung atau 32 gigi permanen. Leco Berrocal mengemukakan bahwa supernumerary teeth berasal dari lamina gigi, karena penyimpangan embriogenik selama pengembangan wajah, dan dengan proliferasi berlebihan sisa-sisa epitel dari lamina gigi yang disebabkan oleh tekanan dari gigi permanen. Faktor-faktor lain seperti mutasi DNA, termasuk anomali maksilofasial seperti bibir sumbing dan langit-langit, displasia cleidocranial dan sindrom Gardner's dapat menimbulkan supernumerary teeth. Supernumerary teeth sangat umum ditemukan karena adanya pengaruh sindrom dan sangat jarang ditemukan tanpa adanya pengaruh sindrom. ${ }^{8,9}$

Manfaat radiografi digital panoramik untuk mengevaluasi insidensi anomali jumlah gigi pada pasien. Radiografi panoramik menguntungkan karena mampu menampilkan gambaran rahang dan gigi disaat yang sama, dengan dosis radiasi yang rendah sehingga radiografi ini sering digunakan pada kebanyakan prosedur kedokteran gigi, termasuk ortodontik, perawatan prostetik, dan bedah, serta dapat digunakan untuk mempelajari gambaran normal maupun abnormal, termasuk anomali jumlah gigi yang terkadang membutuhkan pengamatan lebih dan follow up.

Penelitian dimaksudkan untuk mengetahui berapa prevalensi anomali jumlah gigi ditinjau dari radiografi panoramik di RSGM Universitas Hasanudddin. Manfaat penelitian ini adalah untuk ingin ikut berkontribusi dalam penyedian data prevalensi anomali jumlah gigi ditinjau dari radiografi panoramik.

\section{BAHAN DAN METODE}

Jenis penelitian ini adalah observasional deskriptif, dimana setelah data diambil maka akan disajikan dalam bentuk diagram lalu akan dideskripsikan dalam kalimat deskriptif. Penelitian ini dilaksanakan di Rumah Sakit Gigi dan Mulut Pendidikan Universitas Hasanuddin Makassar bagian Radiologi pada bulan September 2018. Dengan rekomendasi persetujuan etik Nomor: 0053/PL.09/KEPK FKG-RSGM UNHAS/2018. Sedangkan subyek penelitian adalah semua data foto radiografi panoramik pada kasus anomali jumlah gigi di Rumah Sakit Gigi dan Mulut Pendidikan Universitas Hasanuddin pada bulan September 2017 - bulan September 2018.

\section{HASIL}

Data prevalensi anomali jumlah gigi ditampilkan menurut jenis kelamin, usia dan bulan kejadian. Dari hasil penelitian diperoleh data yang mengalami kasus anomali jumlah gigi sebanyak 532 orang. Hasil penelitian disajikan dalam beberapa diagram seperti berikut.

Pada diagram dalam Gambar 1 menunjukkan bahwa jumlah prevalensi anadontia lebih besar pada perempuan. Diagram pada Gambar 2 menunjukkan hasil bahwa yang mengalami anomali anadontia paling banyak pada kelompok usia dewasa. Diagram pada Gambar 3 dapat diketahui bahwa jumlah pasien anadontia paling banyak pada bulan Agustus 2018. Jumlah prevalensi supernumerary teeth lebih besar pada laki-laki seperti dapat dilihat pada diagram pada Gambar 4. Diagram dalam Gambar 5 menunjukkan hasil bahwa yang mengalami anomali supernumerary teeth paling banyak pada kelompok usia remaja dan pada diagram dalam Gambar 6 diketahui bahwa kasus supernumerary teeth sangat jarang terjadi.

\section{DISKUSI}

Penelitian ini menggunakan data foto panoramik yang terdiri atas subyek laki-laki dan perempuan serta terdiri dari kelompok usia remaja (17-25 tahun), dewasa (26-45 tahun), lansia (46-65 


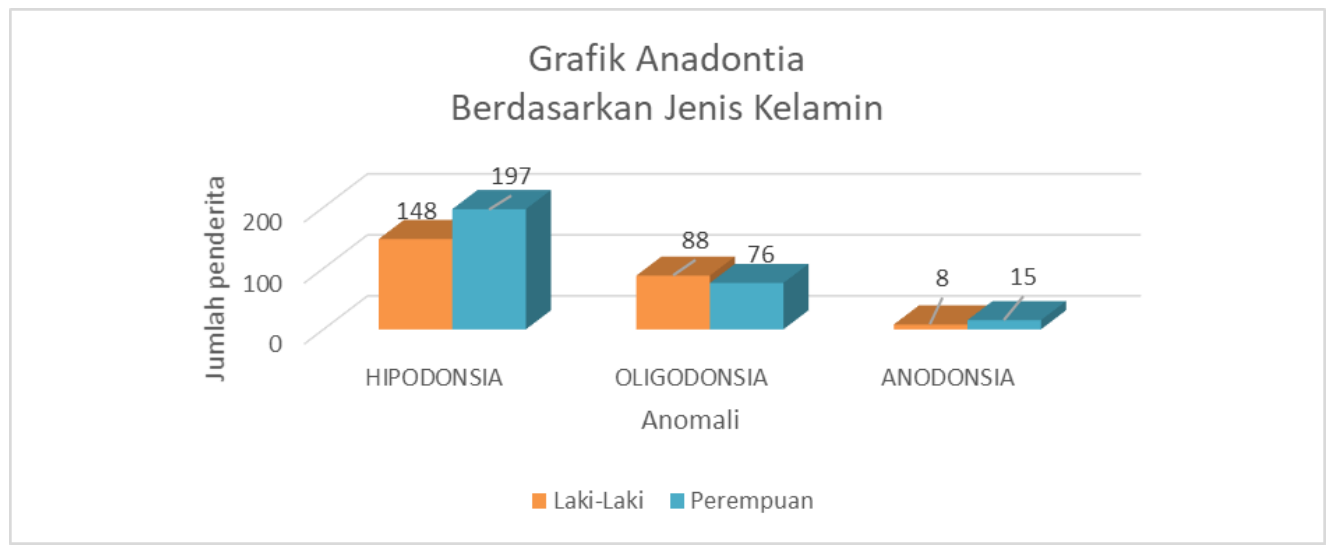

Gambar 1. Diagram prevalensi anadontia berdasarkan jenis kelamin

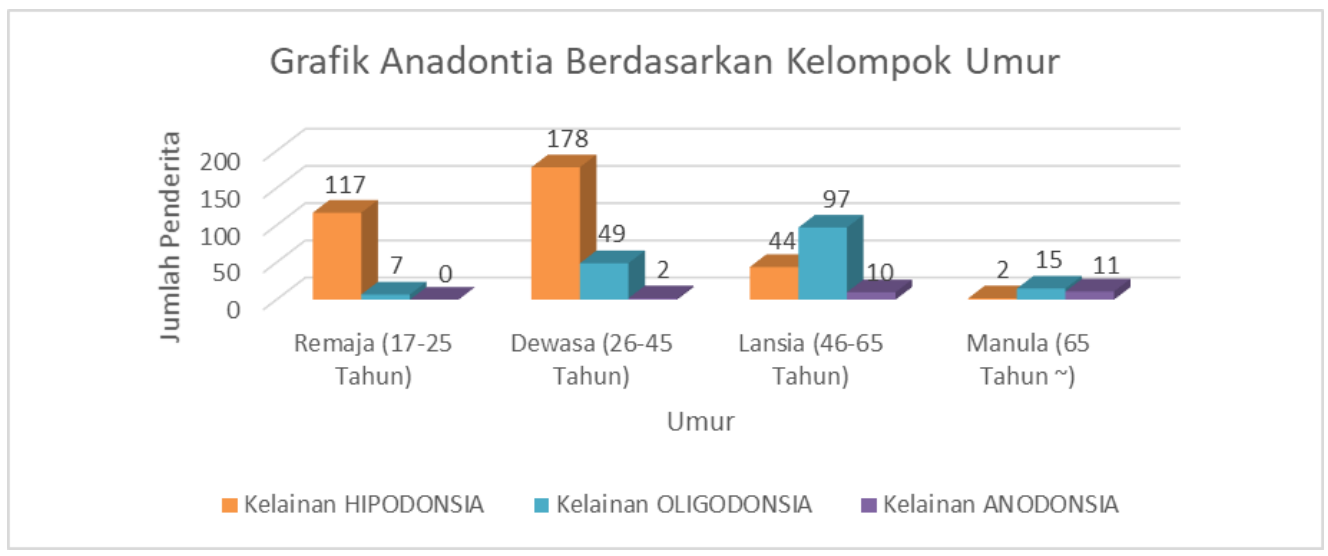

Gambar 2. Diagram prevalensi anadontia berdasarkan kelompok umur

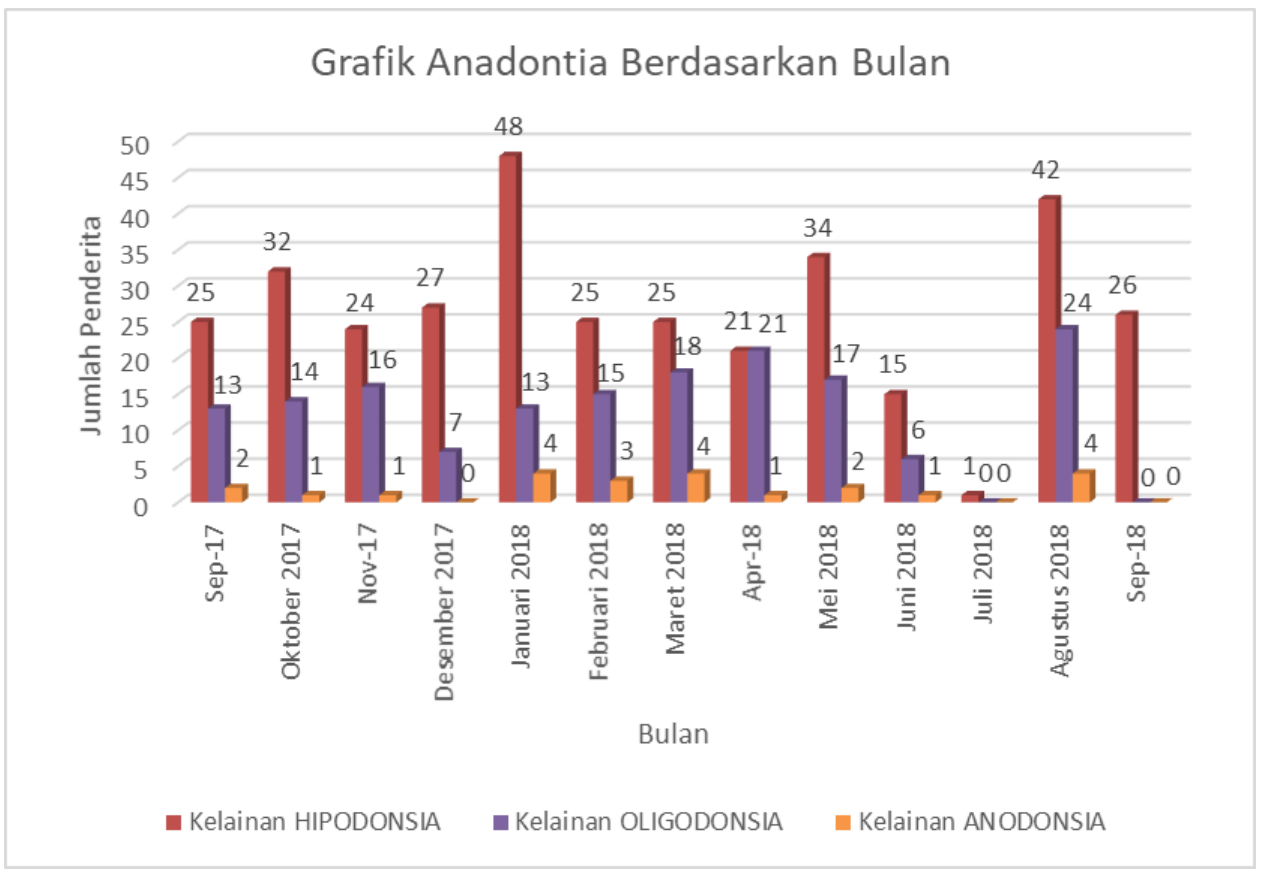

Gambar 3. Diagram prevalensi anadontia berdasarkan bulan

tahun), dan manula (65 tahun ke atas). Klasifikasi dari 532 sampel penelitian, terdapat 244 laki-laki anomali jumlah gigi yang dapat ditentukan melalui (45.86\%) dan 288 perempuan (54.14\%). Jumlah foto panoramik adalah klasifikasi anodonsia, pasien perempuan lebih banyak dari pasien laki-laki oligodonsia, hipodonsia, distomolar, laterodens, dengan rincian yang mengalami hipodonsia dan mesiodens.

sebanyak 197 orang $(68,04 \%)$, oligodonsia sebanyak

Hasil penelitian pada Gambar 1 menunjukkan 76 orang (26,93\%), dan anodonsia sebanyak 15 


\section{Grafik Supernumerary Teeth Berdasarkan Jenis Kelamin}

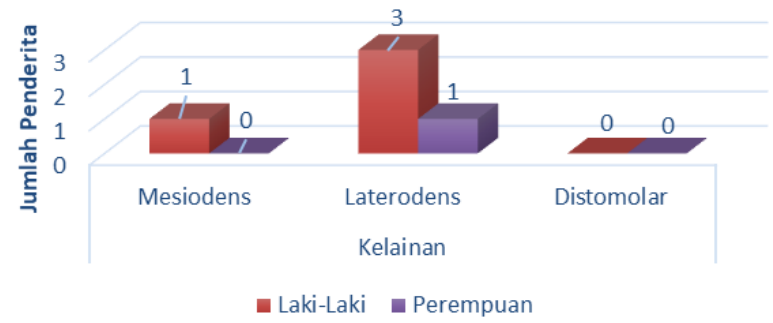

Gambar 4. Uji normalitas (Shapiro-Wilk) dan uji homogenitas (Levene test)

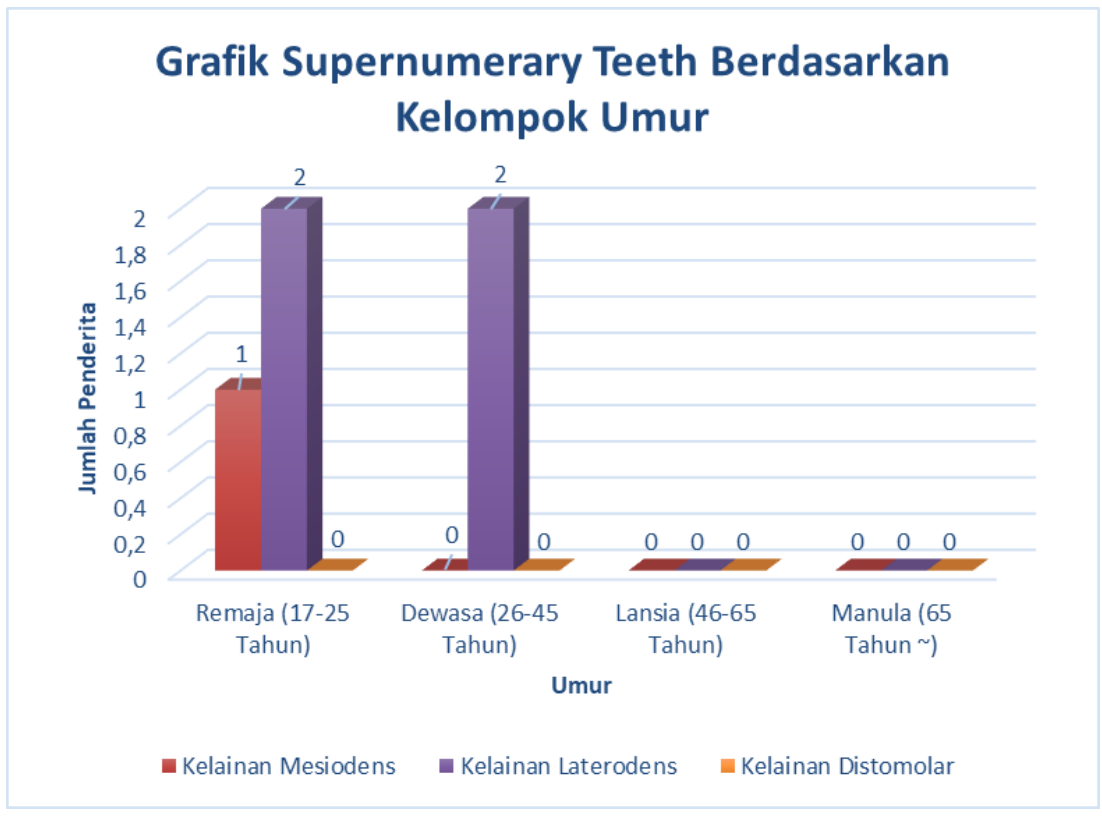

Gambar 5. Diagram prevalensi supernumerary teeth berdasarkan kelompok usia

\section{Grafik Supernumerary Teeth Berdasarkan Bulan}

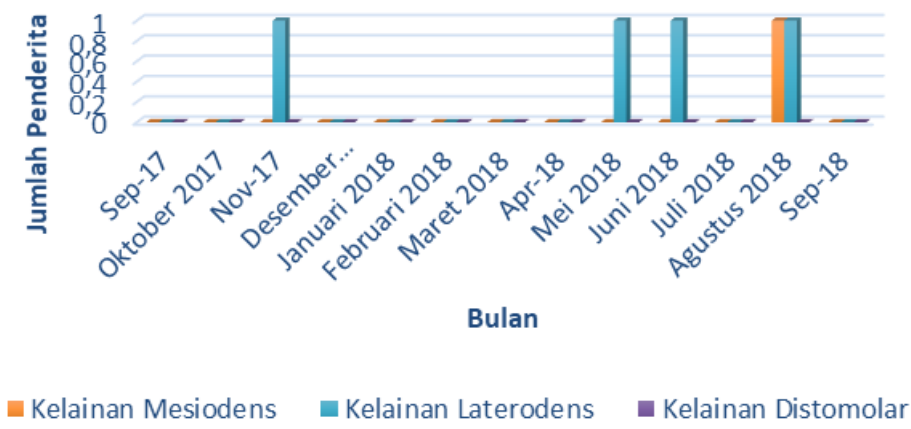

Gambar 6. Diagram prevalensi supernumerary teeth berdasarkan bulan

orang $(5,21 \%)$. Hal ini sejalan dengan penelitian yang telah dilakukan oleh Amini et al. (2014) bahwa perempuan lebih banyak kekurangan jumlah gig dibandingkan laki-laki.

Namun, dalam penelitian yang telah dilakukan oleh Mani et al. (2014) menunjukkan bahwa tidak ada perbedaan signifikan antara laki-laki dan perempuan dalam kasus kekurangan jumlah gigi Kasus kekurangan jumlah gigi cenderung terjadi pada pengguna piranti ortodontik. Selain itu, faktor yang memengaruhi kasus kekurangan jumlah gigi ialah faktor fisiologis, fungsional, dan komplikasi 
emosional (biasanya lebih sering dialami oleh orang dewasa). ${ }^{10,11}$

Hasil penelitian pada Gambar 2 menunjukkan, dari 532 sampel penelitian menunjukkan kelompok usia dewasa (26-45 tahun) sebanyak 229 orang dengan rincian sebagai berikut, dengan hipodonsia sebanyak 178 orang $(77,73 \%)$, oligodonsia sebanyak 49 orang $(21,40 \%)$, dan anodonsia sebanyak 2 orang $(0,87 \%)$. Hasil penelitian ini sejalan dengan hipotesis tentang etiologi untuk kekurangan jumlah gigi seperti kerusakan fisiologis, kerusakan dari dental lamina, kekurangan ruang, anomal fungsional dari dental epithelium, kegagalan dalam regenerasi jaringan mesenkim, kondisi sistemik dan faktor genetik, hal ini sejalan dengan kerusakan fisiologi seiring bertambahnya usia. ${ }^{11}$

Hasil penelitian pada Gambar 2 menunjukkan bahwa terdapat 178 orang pada kelompok usia dewasa $(77,73 \%)$ yang mengalami hipodonsia. Hasil ini sejalan dengan penelitian yang dilakukan oleh Amini et al. (2014) bahwa hipodonsia atau kekurangan jumlah gigi dari enam atau kurang telah dilaporkan sebagai anomali yang paling umum. Hal itu bisa saja mempengaruhi estetik dan fungsi. Sebagai tambahan, hal itu bisa saja mempengaruhi kondisi lain seperti erupsi yang terlambat, anomali ukuran gigi, gigi desidui yang tertinggal, erupsi ektopik kaninus, dan anomal morfologis gigi seperti taurodonsia dan gigi insisivus maksilla yang mengalami peg-shaped. ${ }^{10}$

Bagaimanapun, penelitian tentang prevalensi hipodonsia menunjukkan hasil yang signifikan, tergantung pada diagnosa yang cepat dan rencana perawatan yang efektif. Hal ini penting dalam pencegahan komplikasi hipodonsia, termasuk kerusakan jaringan periodontal, maloklusi, dan rusaknya tulang alveolar. Literatur juga menunjukkan bahwa prevalensi hipodonsia (kecuali pada molar ketiga) pada gigi permanen, berbeda pada tiap populasi. Perbedaan ini dapat disebabkan oleh berbagai hal seperti, teknik pemeriksaan yang berbeda, metode radiografi, umur, jenis kelamin, dan kondisi geografis serta demografis. ${ }^{10}$

Hasil penelitian dalam Gambar 3 menunjukkan bahwa jumlah pasien paling sedikit yakni pada bulan Juli 2018 sebanyak 1 orang (hipodonsia). Hal yang menyebabkan jumlah pasien paling sedikit $d$ bulan Juli 2018 ialah karena pada bulan tersebut bertepatan dengan menjelang waktu masuk kerja atau sekolah setelah libur Ramadhan, dimana sebagian besar orang-orang masih menyiapkan keperluannya sehingga jumlah pasien yang berkunjung untuk melakukan pemeriksaan radiografi panoramik sangat sedikit. Sedangkan jumlah pasien kekurangan jumlah gigi paling banyak pada bulan Agustus 2018 sebanyak 70 orang dengan rincian sebagai berikut: Yang mengalam hipodonsia sebanyak 42 orang $(60 \%)$, oligodonsia sebanyak 24 orang (34,29\%), dan anodonsia sebanyak 4 orang $(5,71 \%)$. Hal yang menyebabkan jumlah pasien paling banyak di bulan Agustus 2018 ialah karena pada bulan tersebut sudah memasuki waktu kerja / kuliah sehingga sebagian besar orang orang sudah berada di kota Makassar dan sudah cukup luang untuk melakukan pemeriksaan radiografi panoramik di RSGM Unhas.

Hiperdonsia atau supernumerary teeth didefinisikan sebagai berlebihnya jumlah gigi pada individu tertentu, yaitu melebihi jumlah gigi normal dari 20 gigi sulung atau 32 gigi permanen. Leco Berrocal mengemukakan bahwa supernumerary teeth berasal dari lamina gigi, karena penyimpangan embriogenik selama pengembangan wajah, dan dengan proliferasi berlebihan sisa-sisa epitel dari lamina gigi yang disebabkan oleh tekanan dari gigi permanen. Faktor-faktor lain seperti mutasi DNA, termasuk anomali maksilofasial seperti bibir sumbing dan langit-langit, displasia cleidocranial dan sindrom Gardner's dapat menimbulkan supernumerary teeth. Supernumerary teeth sangat umum ditemukan karena adanya pengaruh sindrom dan sangat jarang ditemukan tanpa adanya pengaruh sindrom. ${ }^{8,9}$

Hasil penelitian dalam Gambar 4 menunjukkan bahwa terdapat 5 orang yang mengalami anomali kelebihan jumlah gigi dimana laki-laki berjumlah 4 orang dan perempuan berjumlah 1 orang dengan rincian sebagai berikut : yang mengalami mesiodens sebanyak 1 orang (25\%), laterodens sebanyak 3 orang (75\%), dan tidak ada yang mengalami distomolar. Jumlah pasien perempuan sebanyak 1 orang (laterodens). Hal ini sejalan dengan penelitian yang dilakukan oleh Ali et al. (2014) dimana anomali supernumerary teeth lebih sering terjadi pada laki-laki dibanding perempuan dengan perbandingan $2: 1$. Rao dan Chizonga menyatakan bahwa etiologi dari supernumerary teeth adalah multifaktorial, kombinasi antara lingkungan dan faktor genetik. Komplikasi yang berhubungan dengan supernumerary teeth termasuk impaksi, erupsi yang terlambat, erupsi ektopik, over crowded, anomali ruang, dan pembentukan kista folikular. Beberapa kasus supernumerary teeth biasanya asimptomatik dan biasanya dideteksi dengan pemeriksaan radiografi. Pemeriksaan klinis dan radiografi penting untuk mendeteksi supernumerary teeth walaupun pemeriksaan CTScan digunakan sebagai tes diagnostik yang komplemen.

Hasil penelitian pada Gambar 5 menunjukkan bahwa 5 sampel tersebut terbagi ke dalam 2 kelompok usia, yakni kelompok usia remaja dan dewasa. Pada kelompok usia remaja (17-25 tahun) terdapat 3 orang dengan rincian sebagai berikut, yang mengalami mesiodens sebanyak 1 orang $(33,33 \%)$, laterodens sebanyak 2 orang $(66,67 \%)$, dan tidak ada yang mengalami distomolar. Pada kelompok usia dewasa (26-45 tahun) sebanyak 2 orang. Keduanya mengalami laterodens. Sejalan dengan penelitian Demiriz et al. (2015) menyatakan bahwa pada literatur, ditemukan bahwa remaja yang banyak diteliti, dan sebagian besar dari pasien tersebut dilakukan ekstraksi sebelum umur 18 tahun dan umumnya mengalami resiko komplikasi lebih besar beberapa tahun setelahnya. Di sisi lain, beberapa kasus supernumerary teeth ditemukan saat usia dewasa karena beberapa hal, misalnya supernumerary teeth tersebut tidak menyebabkan keluhan atau baru menyebabkan keluhan yang sangat lama, atau pemeriksaan klinis dan radiografi 
dilakukan dengan tidak efektif

Hasil penelitian pada Gambar 6 menunjukkan bahwa 5 sampel tersebut hanya terdapat pada 4 bulan, yakni bulan November 2017 sebanyak 1 orang (laterodens), bulan Mei 2018 sebanyak 1 orang (laterodens), bulan Juni 2018 sebanyak 1 orang (laterodens), dan bulan Agustus 2018 sebanyak 2 orang (mesiodens dan laterodens). Hal ini menunjukkan bahwa kasus supernumerary teeth di Makassar sangat jarang terjadi dilihat dari rentang penelitian selama 1 tahun yang hanya mendapati 5 sampel yang mengalami kasus supernumerary teeth.

\section{SIMPULAN}

Prevalensi anadontia berdasarkan jenis kelamin adalah pasien laki-laki berjumlah 244 orang hipodonsia $(60,66 \%)$, oligodonsia $(36,07 \%)$, dan anodonsia $(3,28 \%)$. Jumlah pasien perempuan sebanyak 288 orang: hipodonsia $(68,04 \%)$ oligodonsia (26,93\%), dan anodonsia $(5,21 \%)$. Prevalensi supernumerary teeth berdasarkan jenis kelamin ialah pasien laki-laki berjumlah 4 orang: mesiodens (25\%), laterodens (75\%). Jumlah pasien perempuan sebanyak 1 orang hanya laterodens.

\section{DAFTAR PUSTAKA}

1. Bilge $\mathrm{NH}$, et al. Invesigation of prevalence of dental anomalies by using digital panoramic radiographs. J Folia Morphologica. 2017: 2-5

2. Anomali gigi akibat gangguan pertumbuhan dan perkembangan. Available from: http://www.scribd.com/ doc/74333664/Kgm-427-Slide-Anomali-Gigi-Akibat-GangguanPertumbuhan-Dan-an. Accessed April 21, 2018.

3. Shetty Pushparaja, Adyanthaya Amith, Adyanthaya Soniya, Sreelatha SV. The prevalence of Hypodontia and Supernumerary teeth in 2469 school children of the Indian population: an epidemiological Study. Indian J Stomatol. 2012; 3(3):150-52.

4. Celigoklu Mevlut, Kamak Hasan, Oktay Husamettin Prevalence and characteristic of supernumerary teeth in a non -syndrom turkish population: Associated pathologies and proposed treatment. Med oral patol oral cir bucal. $2010 \mathrm{Ju}$ 1;15(4): 575-8.

5. Sungkar S, Soenawan H. Agenesis bilateral insisivus sentral rahang bawah. M.I Kedokteran Gigi. Desember 2008; Vol 23 (4).

6. Al-Ani AH, et al. Review Article Hypodontia : An Update on Its Etiology, Classification, and Clinical Management. BioMed Research International. March 2017: 1-3

7. Fariborz Amini, Vahid Rakhshan, Pardis Babaei. Prevalence and pattern of hypodontia in the permanent dentition of 3374 Iranian orthodontic patients. Dental Research Journal. May 2012; Vol. 9

8. Fidele NB, et al. Prevalence and Pattern Occurence of Supernumerary teeth in the North-East Heilongjiang Population of China. Open J of Stomatology. 2016; $6: 47-48$

9. Simoes, F.X.P.C., Crusoe-Rebello I, Neves F.S, Oliveira-santos C, Ciamponi A.L. \& Da Silva Filho O.G. Prevalence of supernumerary teeth in orthodontic patients from southwestern Brazil. Int. J. Odontostomat., 2011; 5(2):199202

10. Amini F, Rakhsan V, Babaei P. Prevalence and pattern of hypodontia in the permanent dentition of 3374 Iranian orthodontic patients. Dental Research Journal. May 2012 : Vol $9(3)$.

11. Mani SA, Mohsin WSY, John J. Prevalence And Pattern of Tooth Agenesis Among Malay Children. Southeast Asian J Trop Med Public Health. March 2014 : Vol 45(2). 